ARTICLE

https://doi.org/10.1038/s41467-019-11541-x

\title{
Mesophilic microorganisms build terrestrial mats analogous to Precambrian microbial jungles
}

\author{
N. Finke ${ }^{1,2}$, R.L. Simister (1) ${ }^{1}$, A.H. O'Neil ${ }^{3}$, S. Nomosatryo ${ }^{4,5}$, C. Henny ${ }^{4}$, L.C. MacLean 6 , D.E. Canfield ${ }^{2}$, \\ K. Konhauser ${ }^{7}$, S.V. Lalonde (1) ${ }^{8}$, D.A. Fowle ${ }^{9} \&$ S.A. Crowe (i) ${ }^{1}$
}

Development of Archean paleosols and patterns of Precambrian rock weathering suggest colonization of continents by subaerial microbial mats long before evolution of land plants in the Phanerozoic Eon. Modern analogues for such mats, however, have not been reported, and possible biogeochemical roles of these mats in the past remain largely conceptual. We show that photosynthetic, subaerial microbial mats from Indonesia grow on mafic bedrocks at ambient temperatures and form distinct layers with features similar to Precambrian mats and paleosols. Such subaerial mats could have supported a substantial aerobic biosphere, including nitrification and methanotrophy, and promoted methane emissions and oxidative weathering under ostensibly anoxic Precambrian atmospheres. High C-turnover rates and cell abundances would have made these mats prime locations for early microbial diversification. Growth of landmass in the late Archean to early Proterozoic Eons could have reorganized biogeochemical cycles between land and sea impacting atmospheric chemistry and climate.

\footnotetext{
${ }^{1}$ Departments of Microbiology and Immunology and Earth, Ocean, and Atmospheric Sciences, University of British Columbia, Vancouver, Canada. ${ }^{2}$ Nordic center for earth evolution (NordCEE), University of Southern Denmark, Odense, Denmark. ${ }^{3}$ Healthy Waterways, Brisbane, Australia. ${ }^{4}$ Research center for Limnology, Indonesian Institute of Sciences (LIPI), Jawa Barat, Indonesia. ${ }^{5}$ GFZ German Research Centre for Geosciences, Potsdam, Germany. ${ }^{6}$ Independent researcher, Halifax, Canada. ${ }^{7}$ Department of Earth and Atmospheric Sciences, University of Alberta, Edmonton, Canada. ${ }^{8}$ European Institute for Marine Studies, Technopôle Brest-Iroise, Plouzané, France. ${ }^{9}$ Department of Geology, University of Kansas, Lawrence, KS, USA. Correspondence and requests for materials should be addressed to S.A.C. (email: sean.crowe@ubc.ca)
} 
$\mathrm{M}$ odern global biogeochemical cycles are distributed across the terrestrial and marine realms. Half of the global primary production, for example, is from algal and cyanobacterial growth in the sunlit surface ocean, while the other half comes from plants inhabiting the continents ${ }^{1}$. More generally, global nutrient cycles are characterized by extensive links between terrestrial and marine ecosystems, forming multiple feedbacks that regulate biological production and climate over geological time-scales ${ }^{2}$. Such biogeochemical feedbacks between land and ocean have operated at least since the emergence of terrestrial plants some 400 million years ago ${ }^{2,3}$, but may have begun much earlier during the Precambrian Eons, when microbial mats developed on land hundreds of millions or even billions of years before the evolution of plants ${ }^{4-8}$. Aquatic biofilms, hypersaline, and marine microbial mats are relatively abundant today, e.g. ${ }^{9-18}$, and these provide insight into the ecology and biogeochemistry of prokaryote-dominated ecosystems. Subaerial examples, however, with the capacity to broadly colonize the early continents ${ }^{8}$, have remained elusive on the modern Earth. Indeed, large-scale colonization of land by microbial mats today is precluded by both animal predation and strong competition with plants for photosynthetic niche-space ${ }^{19,20}$. The lack of information on the ecology, physiology, and biogeochemical functioning of terrestrial microbial mats leaves models for the possible role of such ecosystems in the Precambrian Earth system almost entirely conceptual. Such information, in principle, could be obtained through the study of modern terrestrial mats with features analogous to those inferred from the remains of terrestrial ecosystems preserved in the rock record.

We discovered a subaerial microbial mat growing on exposed ultramafic rock surfaces at the Balambano Hydroelectric Dam on Sulawesi Island, Indonesia (Supplementary Fig. 1). The mat grows on steep outcrops tens of square metres in size (Fig. 1a), accretes to thicknesses up to $6 \mathrm{~cm}$, and has many chemical and biological features that are comparable to the terrestrial microbial communities found in Precambrian rocks ${ }^{4-8}$. Geochemical and microbiological analyses reveal that the mat hosts a diverse photosynthetic microbial community with the metabolic capacity to drive large-scale biogeochemical cycling of $\mathrm{C}, \mathrm{N}$, and other elements released during rock weathering. Quantitative, modelbased reconstructions of the possible role of similar such mats during the Precambrian Eons imply that terrestrial ecosystems could have driven fluxes of matter and energy at global scales, promoted biological evolution, and helped regulate climate well before the emergence of land plants in the Phanerozoic Eon.

\section{Results}

Microbial community composition. The Balambano microbial mat supports a taxonomically diverse assemblage of microorganisms. It is compositionally layered (Figs. 1b and 2), and is largely comprised of filamentous bacteria and their exopolymers, as well as suspended mineral grains (Figs. 1c, d and 2). Cell

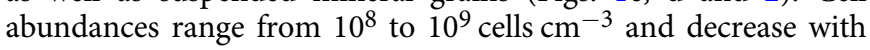
increasing depth in the mat (Supplementary Table 1). The mat is made up of a diverse assemblage of bacteria including an abundance of oxygenic and anoxygenic phototrophs (Fig. 3). Estimates of species richness are on the order of 3000-6000 taxa based on 97\% identity between 16S rRNA genes (Supplementary Fig. 2 and Supplementary Table 2)-comparable to phototrophic communities in the sunlit surface ocean ${ }^{21}$ and hypersaline microbial mats ${ }^{16}$, but less than typical soil microbial communities, which can exceed tens of thousands of species ${ }^{22,23}$.

Beyond information on microbial community diversity, we also identify a number of taxa that can be linked to specific ecological roles. These taxa are reported at the genus level where possible, based on sequence resolution and database matching, and at the family level otherwise. In the upper reaches of the mat, the phototrophic community is dominated by non-heterocystous, filamentous Cyanobacteria (Leptolyngbya and Haloleptolyngbya) and filamentous, photosynthetic Chloroflexi (Roseiflexus, Chloronema, and Candidatus Chloroploca) (Figs. 1d, 3 and Supplementary Table 3). Heterocystous filaments can also be observed (Fig. 1d) in the upper mat and known heterocystous cyanobacteria including Anabaena and Nostoc genera (Fig. 3c), which belong to family I cyanobacterial groups, comprise up to $5.5 \%$ of the photosynthetic community based on $16 \mathrm{~S}$ rRNA gene sequences (Fig. 3; Supplementary Table 3). Cyanobacteria in the mat derive from some of the deepest branching cyanobacterial lineages including Gloeobacter, Thermosynechococcus and the filamentous Pseudanabaena and Leptolyngbya that likely radiated in the Meso- to Neoarchean Eras ${ }^{24,25}$. The base of the mat is enriched in firmicutes, including organisms related to anaerobic Clostridia genera and facultative aerobic Bacilli genera. Throughout the mat, Proteobacteria dominate (Figs. 3a and 4 and Supplementary Fig. 3), with each layer of the mat hosting taxonomically distinct populations. At the family level, Rhodobacteraceae, Aeromonadaceae, and Sphingomonadaceae are most abundant in the upper mat, Rhodobacteraceae, Acetobacteraceae, and Hyphomicrobiaceae dominate in the middle mat, and Pseudomonadaceae, Comamonadaceae, Moraxellaceae, and Burkholderiaceae are most abundant in the bottom layer (Figs. 3a and 4, Supplementary Fig. 3, and Supplementary Table 3). Lineages of the Alpha- and Gammaproteobacteria with metabolic potential for $\mathrm{N}_{2}$ fixation (genera Rhizobium, Azospirillum, and Azomonas) are also present (Supplementary Table 3). Nitrification, furthermore, is implied by the presence of bacteria from the family Nitrosomonadaceae (genus Nitrospira (Supplementary Table 3)), which are known from lab cultures as obligate nitrifiers ${ }^{26}$. Also identified were members of the phyla Verrucomicrobia (genus Candidatus Methylacidiphilum) and Alphaproteobacteria (family Methylobacteriacea) (Supplementary Table 3), both known to grow through methylotrophy or methanotrophy ${ }^{27}$. The archaeal phyla Thaumaracheaota, Bathyarchaeota, and Euryarchaeota were also present (Fig. 3b and Supplementary Table 3), suggesting metabolic potential for archaeal nitrification (genus Candidatus Nitrososphaera) ${ }^{28,29}$ and methanogenesis or $\mathrm{Cl}$ compound metabolism (genera Methanomethylovorans and phylum Bathyarchaeota) $)^{30,31}$, respectively. These subaerial mats thus support taxonomically and metabolically diverse communities with the capacity for biogeochemical cycling of carbon and nitrogen distributed across multiple microbial taxa.

Chemical composition. The Balambano mat microbial community retains bedrock components in the form of mineral grains and amorphous precipitates (Figs. 1c and 2, and Supplementary Fig. 4), which are trapped in the organic matrix of filamentous cells and extracellular polymeric substances (EPS). Such multicellular filaments of cyanobacteria and chloroflexi often stabilize microbial mats. When viewed in cross-section (Fig. 1b, c), the mat exhibits millimeter-scale laminations as well as finer-scale structural features, which include vertically aligned filaments and clusters of opaque inorganic material (Fig. 1c), presumably iron (oxyhydr)oxides. The inorganic chemical composition of the mat (Supplementary Table 4) is mostly $\mathrm{Fe}, \mathrm{Si}$, and $\mathrm{Mg}$, with a mineralogy dominated by X-ray amorphous phases (Supplementary Fig. 4), but also sheet silicates such as nontronite $\left\{\mathrm{Ca}_{\mathrm{O} .1} \mathrm{Fe}_{2}(\mathrm{Si}, \mathrm{Al}) 4 \mathrm{O}_{10}(\mathrm{OH})_{2}-4 \mathrm{H}_{2} \mathrm{O}\right\}$ and pimelite $\left\{\mathrm{Ni}_{3} \mathrm{Si}_{4} \mathrm{O}_{10}(\mathrm{OH})_{2}-5 \mathrm{H}_{2} \mathrm{O}\right\}$. The presence of clay minerals in the mat confirms its capacity to trap and retain material to form protosoil. Organic carbon concentrations are highest (12 wt.\%) in 

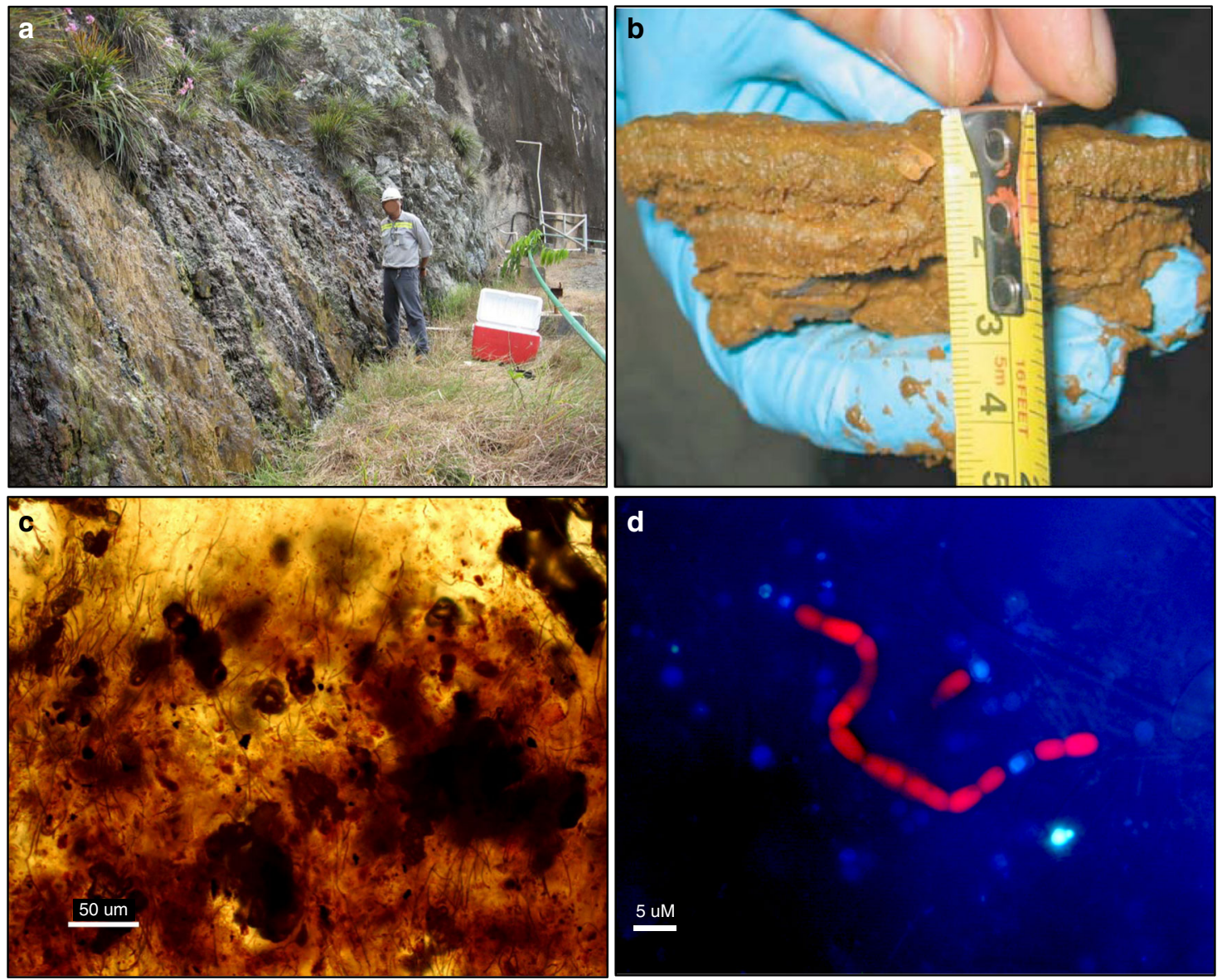

Fig. 1 Images of the Balambano mat. a Field site with microbial mat growing on the outcrop of ultramaphic rock. b Cross section of a freshly sampled microbial mat showing the horizontal layering of the mat and a green, photosynthetic layer close to the mat surface. The orange colour is likely due to the presence of iron(oxy)hydroxides. c Thin section of the microbial mat showing trapped opaque minerals suspended in a translucent matrix containing abundant microbial filaments. d Fluorescence microscopy image of filamentous cyanobacteria in the mat showing presence of heterocystous cyanobacteria, red is from chlorophyll autofluorescence and the heterocyst is identified by its lack of chlorophyll

the upper $2 \mathrm{~mm}$ of the mat, where the isotopic composition of organic $\mathrm{C}\left(\delta^{13} \mathrm{C}\right)$ is $-33 \%$ (Supplementary Fig. 5), indicative of photosynthetic $\mathrm{C}$ fixation ${ }^{32}$. Deeper in the mat, organic carbon concentrations decline to $1 \mathrm{wt} . \%$, with isotopic compositions as light as $-41 \%$ (Supplementary Fig. 5), indicating incorporation of ${ }^{13} \mathrm{C}$-depleted carbon, likely through methanotrophy. With $10^{8}-10^{9}$ cells $\mathrm{cm}^{-3}$ cellular biomass makes up from 0.001 to $20 \%$ of the total organic C in the mat (see Methods below). Organic N reaches nearly $1 \mathrm{wt} . \%$ in the surface of the mat with a C:N ratio of 15-higher than the Redfield ratio of around 6 that typifies marine phytoplankton today ${ }^{33}$ and in the past (Supplementary Fig. 5) ${ }^{34}$. The $\mathrm{N}$ isotopic composition of organic matter (OM) ranges from -3.4 to $-0.6 \%$ (Supplementary Fig. 5), indicative of biological fixation of atmospheric $\mathrm{N}_{2}$ (ref. ${ }^{35}$ ).

Biological production and growth rate. Physiological measurements and mass balance considerations constrain the metabolic potential and overall biogeochemical activity of the Balambano mat. Measurements of photosynthesis revealed net $\mathrm{O}_{2}$ production of $23 \mathrm{mmol} \mathrm{m}^{-2} \mathrm{~d}^{-1}$ (Fig. 5 and Table 1), while mass balance calculations of mat growth suggest in situ organic carbon accretion rates of $20 \mathrm{mmol} \mathrm{m}^{-2} \mathrm{~d}^{-1}$ (Supplementary Fig. 6 and Table 1). Measured $\mathrm{CH}_{4}$ production rates were up to $4.1 \mathrm{mmol} \mathrm{m}^{-2} \mathrm{~d}^{-1}$ (Supplementary Fig. 6 and Table 1). Together, these rates indicate that both retention of $\mathrm{OM}$ and $\mathrm{CH}_{4}$ loss are important sinks of reduced carbon in the mat that balance net $\mathrm{O}_{2}$ production (Supplementary Fig. 6 and Table 1).

\section{Discussion}

Many of the Balambano mat features are similar to the geochemical, mineralogical, fossil, and structural evidence for the presence of microbial life on the continents and early paleosols during the Archean Eon ${ }^{4,8,36}$. The filamentous morphology of the Balambano mat may be essential for the stabilization of subaerial mats and is amenable to preservation as readily identifiable microfossils, such as those found in Precambrian terrestrial rocks ${ }^{4,8}$. In fact, a number of microbial lineages that have been interpreted from Archean paleosols, such as Actinobacteria, purple sulphur bacteria, and methanogenic Archaea ${ }^{37}$, are found in the Balambano mat (Fig. 3). At a larger scale, mineral trapping (Fig. 1c), and growth through the accretion of compositionally distinct layers (Figs. $1 \mathrm{~b}$ and 2), can leave characteristic laminated features in the rock record akin to structures recognized as stromatolites in Archean terrestrial ${ }^{38}$ and marine ${ }^{39,40}$ rocks. Taken together, the structural support provided by filaments to the Balambano mat and the putative filamentous nature of early terrestrial stromatolite communities suggest that the evolution of multicellularity in the form of filamentous bacteria may have been requisite for the proliferation of thick, subaerial microbial mats and their preservation in the rock record. Photosynthetic and methanogenic organisms in the mat impart characteristic 


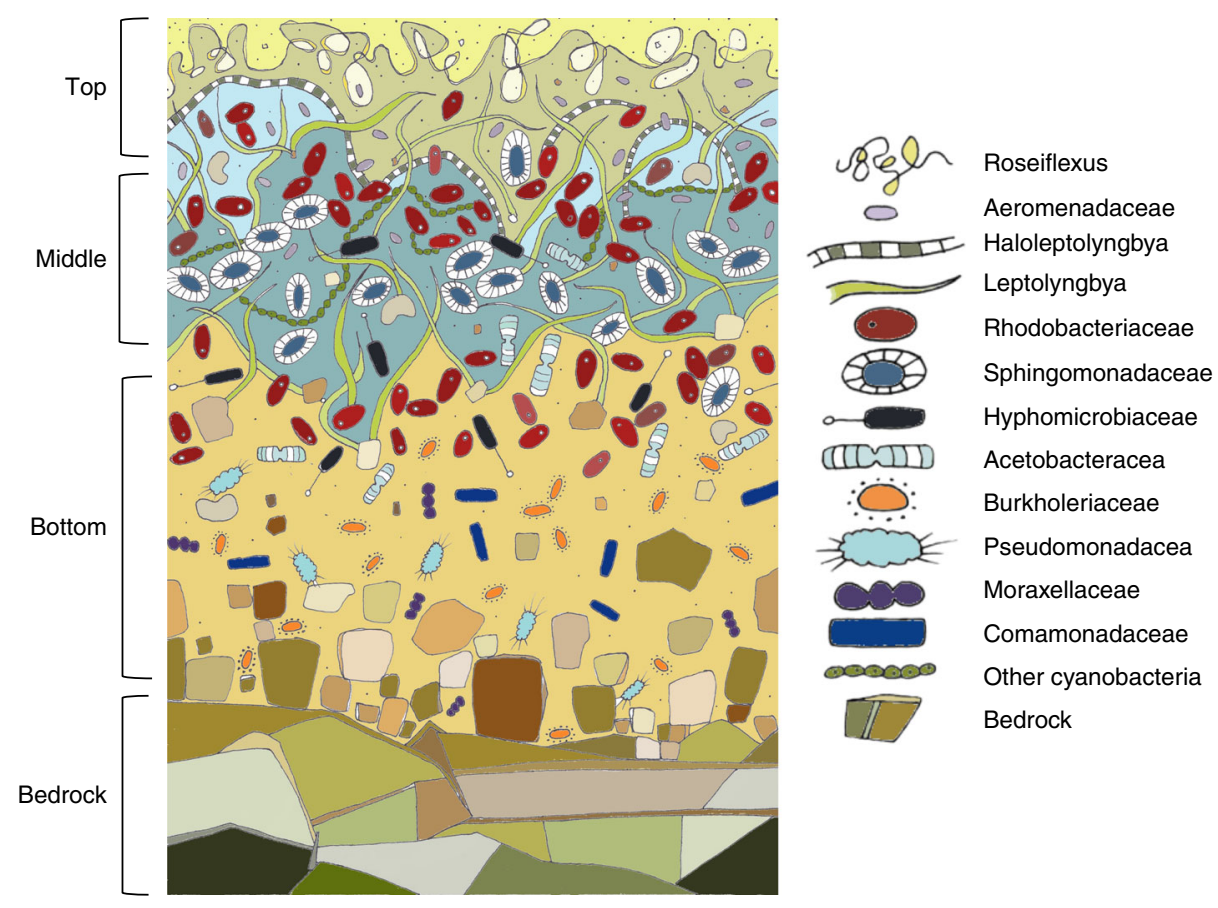

Fig. 2 Stylized illustration of Balambano microbial mat. The illustration depicts the positions of major microbial taxa, weathered rock fragments, and underlying bedrock. Cells not drawn to scale

a

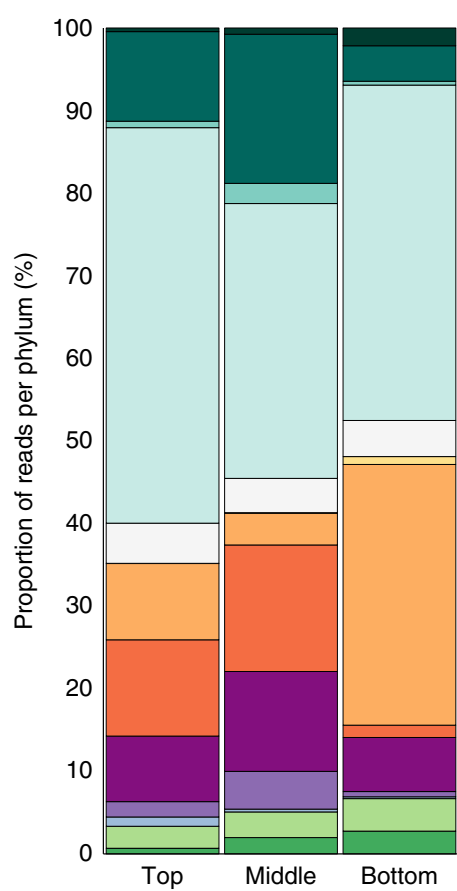

- Other $^{*}(<1 \%$ total reads $)$

- Unclassified Bacteria

$\square$ Verrucomicrobia

$\square$ Proteobacteria

$\square$ Planctomycetes

$\square$ Nitrospirae

$\square$ Firmicutes

$\square$ Cyanobacteria

- Chloroflexi

$\square$ Bacteroidetes

$\square$ Armatimonadetes

$\square$ Actinobacteria

$\square$ Acidobacteria b

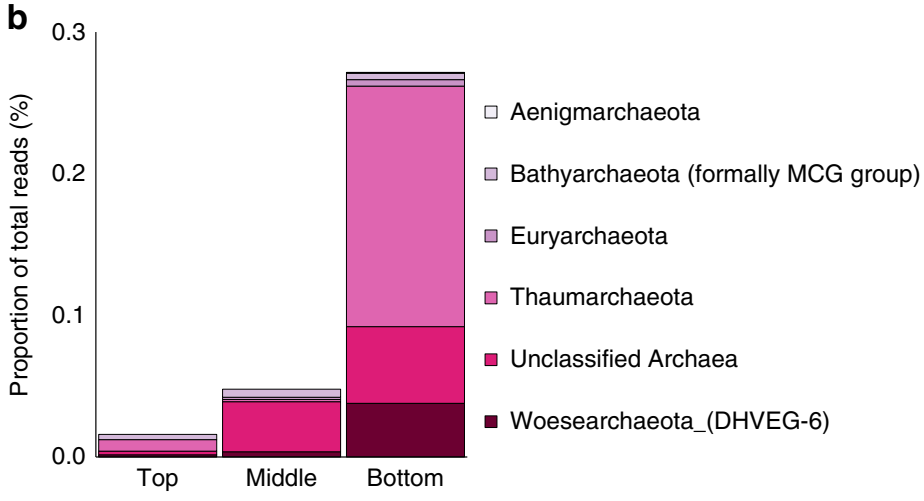

C

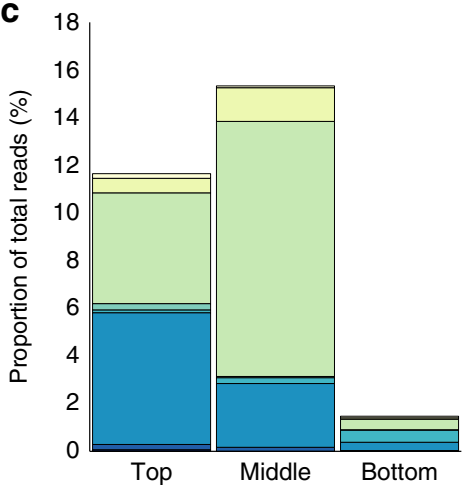

$\square$ Other $(<0.05 \%$ total reads)

$\square$ Unclassified Cyanobacteria

$\square$ Leptolyngbya

$\square$ Gloeocalita

$\square$ Gloeobacter

๑ Familyl Unclassified

Chroococcidiopsis

- Arthronema

Fig. 3 Composition of the Balambano mat microbial community. Distribution of Illumina 16S rRNA gene sequences are shown per bacterial phylum (a), per archaeal phylum (b) and per cyanobacterial genera (c), in three sections of the microbial mat (top =0-2 mm; middle = 2-5 mm; ottom = 5-20 mm). The number of sequence reads per phylum is calculated as a percentage of the total sequence reads for each sample. ${ }^{\star}$ Other represents reads that contributed $<1$ and $0.05 \%$ of the total number of reads for $A$ and $C$, respectively 


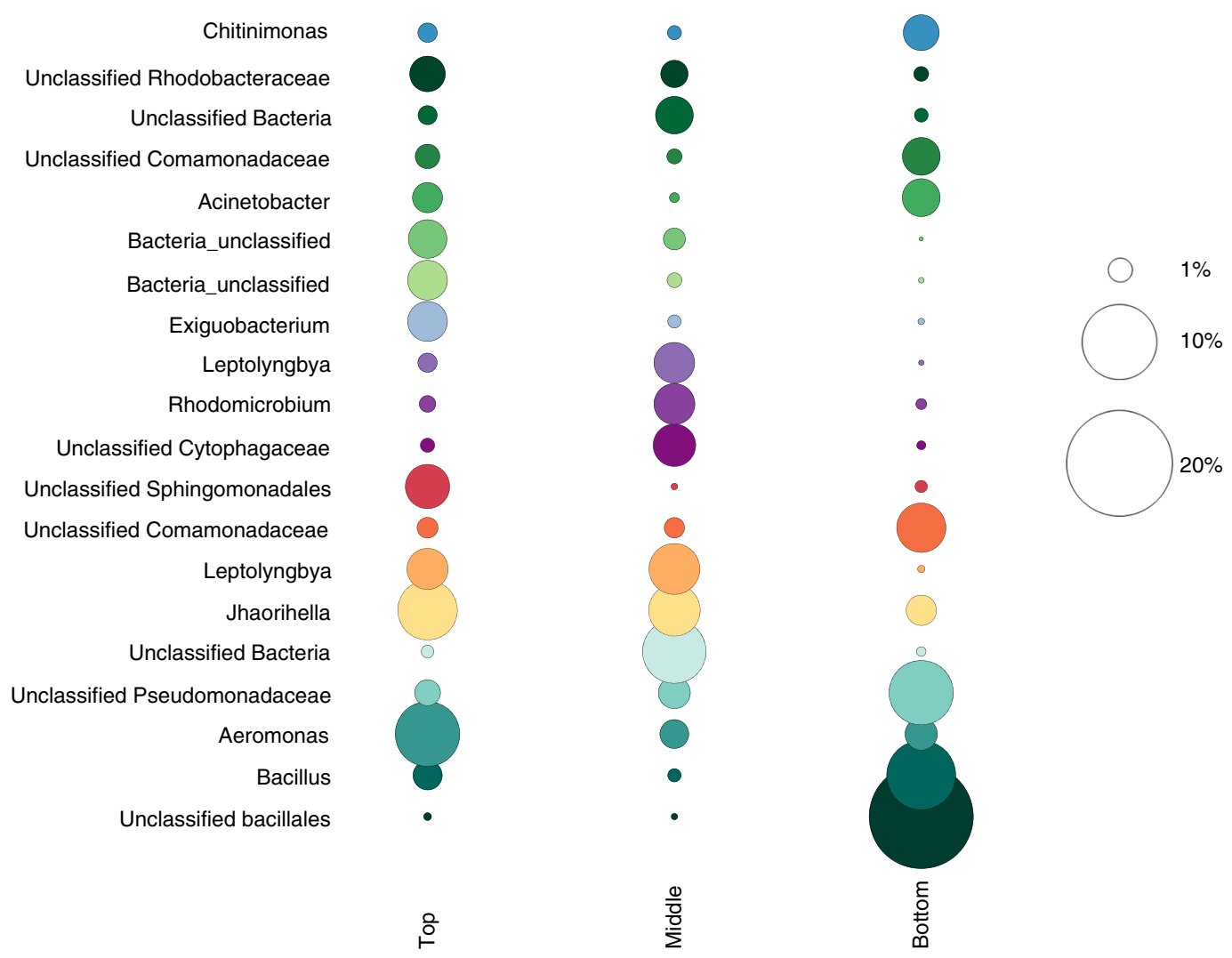

Fig. 4 Detailed composition of Balambano microbial mat community. The top 20 most abundant taxa (at $97 \%$ sequence identity, commonly accepted as defining the species level), in the top, middle, and bottom microbial mat sections

geochemical signals such as ${ }^{13} \mathrm{C}$-depleted $\mathrm{OM}$, as well as elemental stoichiometries, that can ultimately be recorded as fossil $\mathrm{OM}$ in paleosols ${ }^{7}$ and fossilized microbial mats ${ }^{8}$. Notably, mat retention of inorganic material (Fig. 1b, c) provides a weathering environment conducive to clay mineral formation and soil accretion $^{41}$ - processes critical to early soil development, mineral evolution $^{42}$, and the preservation of weathering products as paleosols. By extension, microbial mats would also have influenced the delivery of weathering products to oceans, and the burial of $\mathrm{OM}$ in marine sediments. For example, terrestrial microbial activity has been invoked to explain increased nutrient, sulphate, and trace element fluxes to the oceans in the Archean Eon $^{5,43,44}$, and enhanced delivery of clay minerals to oceans in the Neoproterozoic Era ${ }^{41}$.

Physiological information from the Balambano mats can be used to infer the possible biogeochemical role of similar mats during the Precambrian Eons. We note that modern microbial communities are imperfect analogues to Precambrian microbial communities, as many of the specific taxa that comprise these communities likely arose relatively recently ${ }^{45}$. Nevertheless, most metabolic potential hosted within these taxa emerged early in Earth's history ${ }^{46}$ and is likely retained at the community level such that the capacity to drive biogeochemical cycling is conserved through time despite taxonomic reshuffling of metabolic potential through horizontal gene transfer ${ }^{47}$. We thus argue that the metabolic potential and biogeochemical functioning of Balambano mat makes a good analogue for similar mats in the Precambrian Eons, but recognize that the taxonomic composition of the modern mat is unlikely to reflect the taxonomic composition of Precambrian mats. Relationships between taxonomy and function remain controversial ${ }^{48}$, but when better known, may prove important considerations for establishing and interpreting analogue systems.
Rates of photosynthetic productivity and OM accretion in Balambano mat are similar, on an area-specific basis, to moderately productive coastal marine waters or perennial grasslands today ${ }^{1}$, implying that if subaerial mats were widespread on the Precambrian continents, then they would have played a key role in global carbon and oxygen budgets (Fig. 6). Upper estimates for gross marine productivity in the Precambrian Eons are between 170 and $500 \mathrm{Tmol} \mathrm{yr}^{-1}$ (ref. ${ }^{49}$ ). Respiration in Balambano mat consumes $66 \%$ of the $\mathrm{O}_{2}$ produced giving a gross production of $38 \mathrm{mmol} \mathrm{m}^{-2} \mathrm{~d}^{-1}$ (Table 1) or $14 \mathrm{Mmol} \mathrm{C} \mathrm{km}^{-2} \mathrm{yr}^{-1}$, similar to values estimated for Archean benthic freshwater mats ${ }^{44}$ and at the lower end of rates (range 6-1200 $\mathrm{mmol} \mathrm{m}^{-2} \mathrm{~d}^{-1}$, average 240 mmol m${ }^{-2} \mathrm{~d}^{-1}$, Supplementary Table 5) measured in hypersaline, marine, and aquatic environments (Supplementary Table 5). Applying our measured rates of gross productivity to an area equivalent to, for example, $5 \%$ of the late Archean land area $\left(2.5 \times 10^{7} \mathrm{~km}^{2}\right.$ (ref. $\left.{ }^{50}\right)$, lower end of values reported ${ }^{51}$ for the Neoarchean) yields a terrestrial productivity of $17 \mathrm{Tmol} \mathrm{yr}^{-1}$ (Fig. 6), or up to $10 \%$ of total estimated global production with minimal coverage of land surfaces. Benthic lacustrine mats could contribute to some of this production, but modern lakes and rivers cover only $\sim 2 \%$ of the land surface ${ }^{52}$ and just a small fraction of that is suitable habitat for mat growth (Fig. 6). The fraction of the available land mass colonized by mats would depend on precipitation patterns and water availability. Modern climate and topography allow development of forests and grasslands on $\sim 55 \%$ of today's land surface ${ }^{53,54}$, which when translated to the Archean would have allowed terrestrial mats to contribute up to $\sim 190 \mathrm{Tmol} \mathrm{yr}^{-1}$ to global productivity. Landmasses in the tropics today are typically overgrown with dense forest and 'tangled' vegetation referred to as jungles. We suggest, by analogy, that tropical regions in the Archean Eon were similarly overgrown with dense and 'tangled' microbial communities, such as 


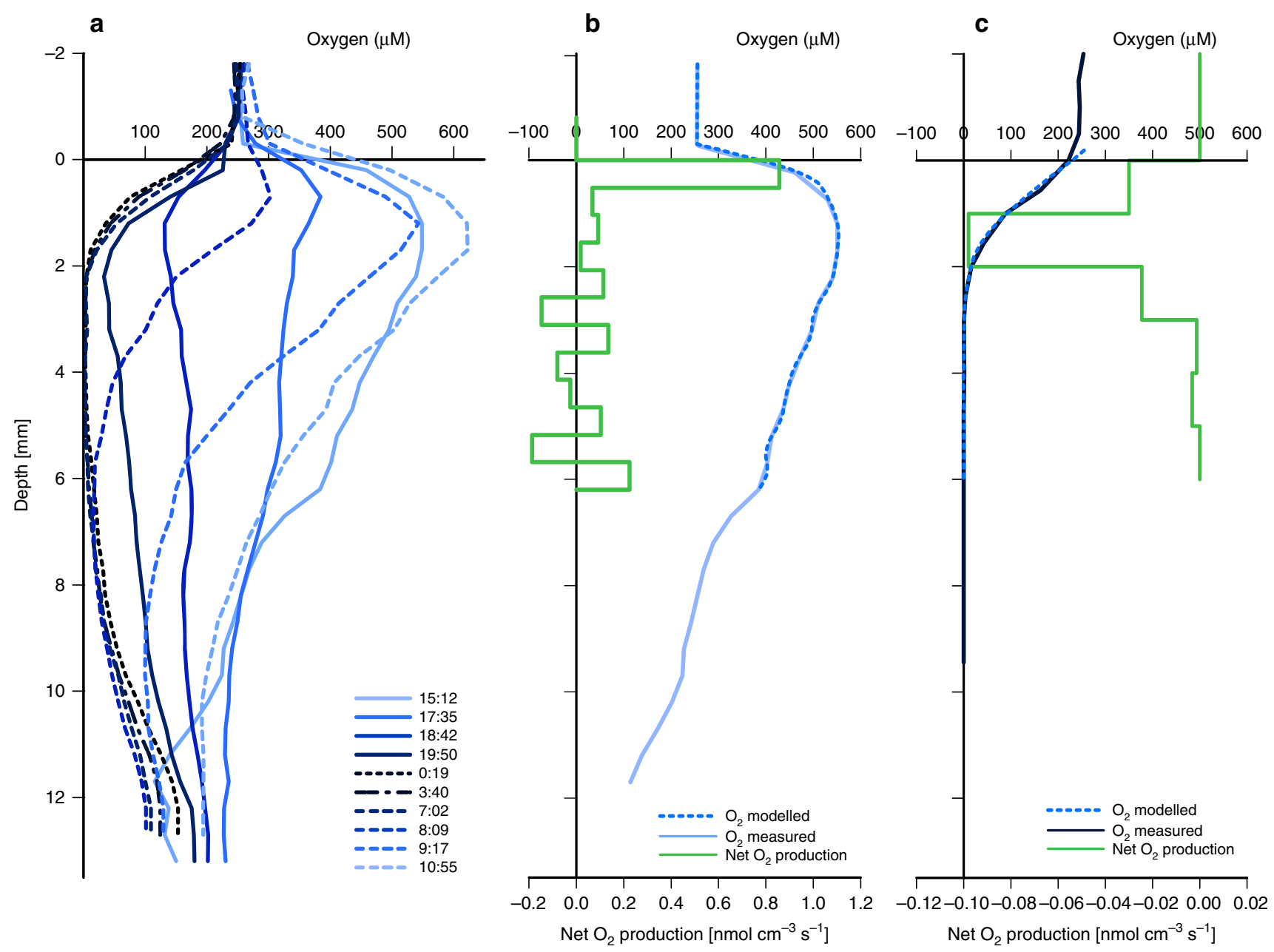

Fig. 5 Profiles of oxygen concentrations as a function of depth in the mat. a Diel oxygen profiles measured in the greenhouse every $2 \mathrm{~h}$. $\mathbf{b}$ Net oxygen production modelled from the 15:12 profile from a using a 1D transport-reaction model ${ }^{72}$. c Net oxygen production modelled from the 3:40 profile from Fig. 3a using a 1D transport-reaction mode ${ }^{72}$. Respiration is restricted to the oxic surface layers. High oxygen concentrations during the day likely stimulate respiration throughout the mat. The areal rates calculated from the rate profiles are presented in the box model (Supplementary Fig. 5) and used for the calculations in Table 1 and Fig. 6

Table 1 Gross and net oxygen production

\section{Single sources and sinks}

1D model

$\mathrm{O}_{2}$ flux atmosphere + rock

$\mathrm{CH}_{4}$ flux atmosphere $+\mathrm{OM}$ production

Single sources and sinks

$1 \mathrm{D}$ model net $\mathrm{O}_{2}$ production + respiration

$\mathrm{O}_{2}$ flux atmosphere + rock + respiration

$\mathrm{CH}_{4}$ flux to atmosphere $+\mathrm{OM}$ production + respiration

\begin{tabular}{|c|c|}
\hline Net $\mathrm{O}_{2}$ production ( $\mathrm{mmol} \mathrm{m}^{-2} \mathrm{~d}^{-2}$ ) & Method \\
\hline 23 & 1 \\
\hline 8.4 & 2,3 \\
\hline 24 & 4,5 \\
\hline Gross $\mathrm{O}_{2}$ production $\left(\mathrm{mmol} \mathrm{m} \mathrm{m}^{-2} \mathrm{~d}^{-2}\right.$ ) & Method \\
\hline 38 & 1,6 \\
\hline 23 & $2,3,6$ \\
\hline 39 & $4,5,6$ \\
\hline
\end{tabular}

1, 1D transport reaction based on daytime greenhouse profile; 2, flux determination from daytime greenhouse profile; 3, flux determination of in situ profile; 4, in situ mat accretion; 5, headspace analysis in dark mat incubation; 6, 1D transport reaction modelling based on night time greenhouse profiles, see also Supplementary Fig. 4

OM organic matter

the Balambano mat, that thus formed Precambrian continental jungles.

Combining cell counts and C-fixation rates allows us to evaluate the possible importance of subaerial microbial mats in driving evolutionary processes during the Archean Eon. At $10 \%$ surface coverage, microbial mats likely harboured tenfold fewer microbial cells, globally, than the Archean surface ocean (Supplementary Table 6 (ref. $\left.{ }^{55}\right)$ ). Based on our measurements in Balambano mat, global rates of cell division, on the other hand, could have been similar in the two ecosystems (Supplementary Fig. 7 and Supplementary Table 6), and this implies similar annual probability for genetic mutations on land and in the ocean. In microbial mats, cells also live in much closer proximity than in the open ocean, which fosters horizontal gene transfer, and thus rates of genetic exchange are expected to be higher in mat communities than in the ocean. Together, similar mutation rates and higher frequencies of horizontal gene transfer in landbased ecosystems would thus have made them prime locations for 


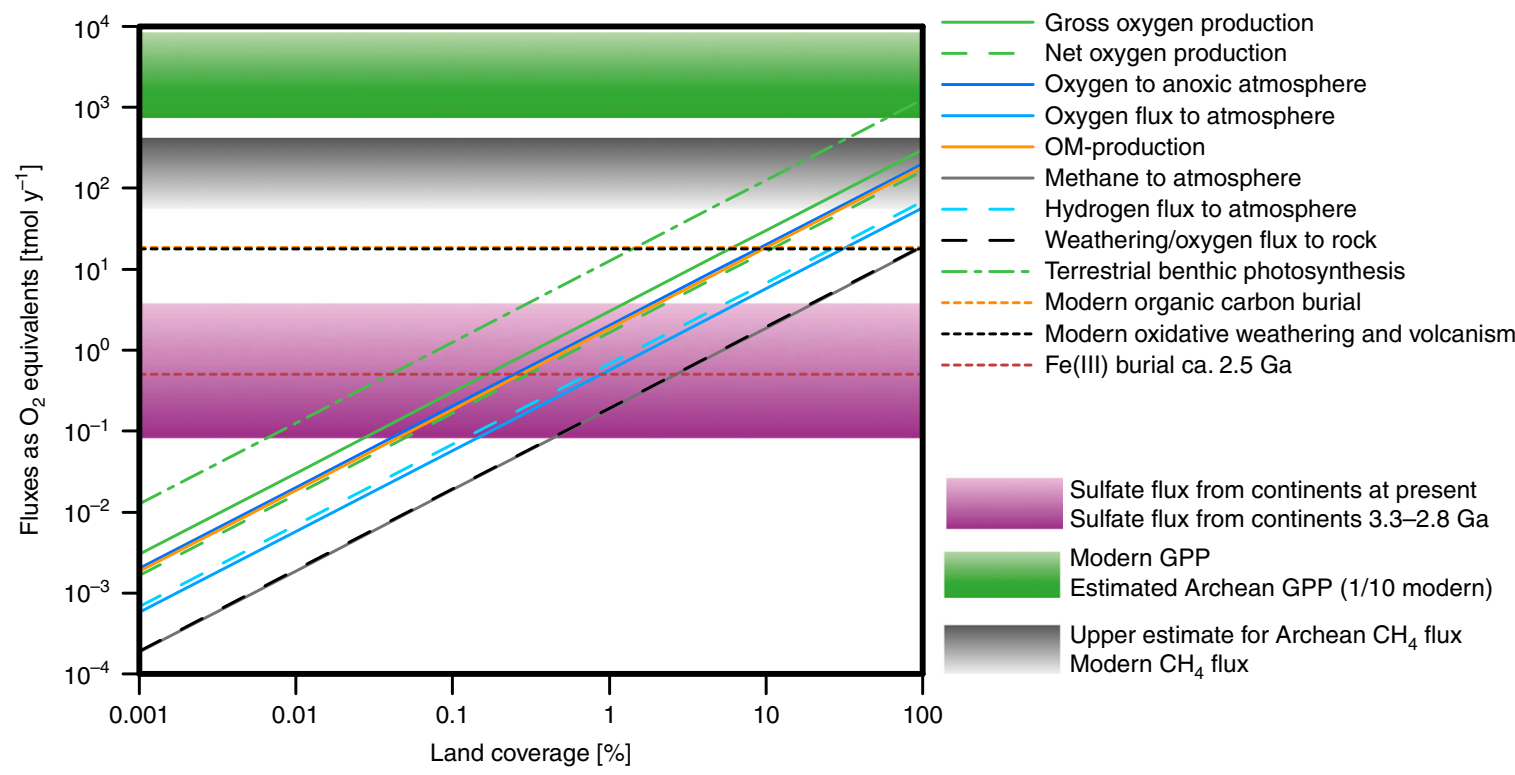

Fig. 6 Global elemental budgets and fluxes. Land coverage is based on a total land surface area of $2.5 \times 10^{7} \mathrm{~km}^{2}$ ( ref. ${ }^{50}$ ). At about $0.02 \%$ land coverage, the measured gross oxygen production could account for the present sulphate flux and would exceed historic values. At a coverage of about $1 \%$, it would match modern oxidative weathering and volcanism, or modern organic carbon burial. A coverage of more than $100 \%$ is required to reach the estimated Archean gross marine primary productivity. Shaded areas for sulphate flux, methane flux, and gross primary productivity refer to fluxes ranging from Archean (darker colours) to present (lighter colours) values. Horizontal lines represent global production, diagonal lines represent terrestrial production dependent on land coverage (modified after ${ }^{44}$ ). Values according to ref. ${ }^{44}$ were recalculated for $2 \%$ of land surface to be covered by rivers and lakes ${ }^{52}$

microbial evolution in the Archean Eon, implicating continental mats as possible drivers of the Archean expansion in biological diversity ${ }^{46}$.

Continental microbial communities have also been implicated in oxidative weathering, global oxygen budgets, and the evolution of atmospheric $\mathrm{O}_{2}$ and $\mathrm{CH}_{4}$ in the Precambrian Eons ${ }^{44,56}$. To directly test the potential role of continental mat communities in global $\mathrm{O}_{2}$ cycling, we partitioned net mat $\mathrm{O}_{2}$ sinks between loss to the atmosphere and consumption through oxidative weathering of the underlying bedrock (Supplementary Figs. 6, 8, and 9, and Table 1). Under the modern oxygenated atmosphere, $6.3 \mathrm{mmol}$ $\mathrm{m}^{-2} \mathrm{~d}^{-1}$ or $16 \%$ of gross $\mathrm{O}_{2}$ production escapes the mat surface to the atmosphere, $6 \%$ is consumed through weathering of the underlying bedrock, and the balance channelled through respiration (Supplementary Figs. 6, 8, and 9, and Table 1). Under low- $\mathrm{O}_{2}$ early-to-mid-Archean atmospheres, $24 \mathrm{mmol} \mathrm{m}^{-2} \mathrm{~d}^{-1}$ or up to $70 \%$ of the gross $\mathrm{O}_{2}$ production would escape from the mat surface (Supplementary Figs. 6, 8, and 9, and Table 1). With minimal continental freeboard, such an $\mathrm{O}_{2}$ flux from continental mats would be entirely consumed through reactions with atmospheric $\mathrm{O}_{2}$ sinks even at $100 \%$ land coverage ${ }^{44}$ (Fig. 6). Growth of landmass in the late Archean to early Palaeoproterozoic to about $10 \%$ of the Earth surface ${ }^{50}$, however, could have allowed $\mathrm{O}_{2}$ effluxes from continental mats to overcome these sinks and $\mathrm{O}_{2}$ to accumulate in the atmosphere, if residual organic carbon was ultimately buried in marine sediments, even with minimal contribution from marine or benthic freshwater photosynthesis. Rates of organic carbon reoxidation would decrease upon export from the mat into surrounding anoxic environments ${ }^{57}$ promoting transport to the oceans, burial in sediments, and net oxygenation of the atmosphere. At the same time, $\mathrm{CH}_{4}$ effluxes from terrestrial microbial mats to the atmosphere could have contributed to atmospheric haze formation in the Archean $\operatorname{Eon}^{58}$ and climate warming throughout the Archean and Proterozoic Eons ${ }^{56}$. The combined effects of mat $\mathrm{O}_{2}$, organic $\mathrm{C}$, and $\mathrm{CH}_{4}$ efflux should be investigated further, but overall the growth of continental landmass would have redistributed biogeochemical cycles between the oceans and continents with strong potential to alter the atmospheric chemistry between the late Archean and early Proterozoic Eons.

Increased fluxes of nutrients and redox-sensitive trace metals to the oceans 100's of millions of years before the Great Oxidation Event $(\mathrm{GOE})^{5,59-61}$ are used to infer high atmospheric oxygen levels in the late Archean Eon. Indeed, there is abundant evidence for the emergence of oxygenic photosynthesis by at least the Mesoarchean Era and this comes from both geochemical proxies $^{59,61,62}$ and molecular phylogenies ${ }^{25,63}$. Rapid recycling of oxygen produced in terrestrial microbial mats through respiration or coupled to rock weathering and sulphide mineral oxidation, however, would have allowed for delivery of such redox tracers to the oceans even under an anoxic atmosphere ${ }^{44}$. It is thought that aerobic respiration may have evolved before oxygenic photosynthesis ${ }^{64}$, but alternatively could have emerged as the immediate response ${ }^{65}$. A $0.02 \%$ coverage of the late Archean land mass ${ }^{50}$ by continental photosynthetic microbial mats would have been sufficient to produce the sulphur flux proposed for the Mesoarchean, and at a $1 \%$ coverage, a modern sulphur flux can be sustained $^{5}$ (Fig. 6). The presence and activity of nitrogen fixing and nitrifying bacteria in the mat also implies that terrestrial mats could have supplied the coastal ocean with oxidized $\mathrm{N}$-species under an anoxic atmosphere, as previously suggested for biological soil crusts ${ }^{43}$. Nitrification likely emerged in response to oxygenic photosynthesis ${ }^{66}$, even though widespread evidence for nitrification at global scales seems only to emerge following the $\mathrm{GOE}^{67}$. Based on our measured net production and $\mathrm{C}: \mathrm{N}$ ratios, the mats could have supplied $1 \mathrm{Tmol} \mathrm{yr}^{-1}$ nitrate to the coastal ocean and such a flux may be recorded in late Archean sedimentary $\mathrm{N}$-isotope signals ${ }^{68,69}$. Mat-enhanced fluxes of nitrate and sulphate could also have stimulated coastal marine primary production, fuelling sulphate reduction and supporting the development of late Archean sulphidic oceans ${ }^{43,70}$.

Our work on Balambano mat qualitatively and quantitatively shows how oxygenic photosynthesis supports taxonomically and metabolically diverse microbial jungles that can drive fluxes of 
matter and energy at global scales. Export of nutrients from terrestrial mats to the coastal ocean can be sustained by aerobic metabolisms and weathering reactions that operate within the mat and largely independent of atmospheric oxygen. Terrestrial mat $\mathrm{CH}_{4}$ effluxes can contribute to atmospheric chemistry and climate, possibly playing an outsized role compared to marine communities in the Proterozoic Eon ${ }^{56}$. In this way, terrestrial microbial jungles would have established the first links between biogeochemical cycles on land and in the ocean during the Archean Eon and these links could have continued throughout the Proterozoic Eon until plants colonized the continents and usurped the microbial continental biosphere in the midOrdovician some $470 \mathrm{Ma}$.

\section{Methods}

Sampling site. Samples were collected from an outcrop of ultramafic bedrock exposed during the construction of the Balambano hydroelectric dam (Supplementary Fig. 1). The dam was constructed in 1997 and the samples collected in 2006 and again in 2009, 9-12 years after bedrock exposure. The outcrop measures several tens of square-meters and is periodically wet by direct precipitation as well as overland flow (Fig. 1a). The outcrop is mostly covered by the microbial mat, but bedrock is exposed in places, and is also partly covered by grasses. The maximum observed thickness of the mat was $6 \mathrm{~cm}$, but typical observations were $\sim 3 \mathrm{~cm}$ (Fig. 1b).

Mat description. The microbial mat forms distinct layers that vary on a millimeter-centimeter scale (Fig. 1b). The mat is mechanically robust allowing removal of intact square-decimeter sections. The dominant colour of the mat is ochre, which is characteristic of iron oxyhydroxides. A green layer is visible at about 2-5 mm depth, coinciding with a peak in oxygen concentrations (Fig. 5 and Supplementary Fig. 10). Light microscopy revealed opaque minerals and rock fragments trapped in a translucent matrix that also hosted microbial filaments (Fig. 1c). Fluorescence microscopy of individual filaments revealed the presence of heterocystous cyanobacteria (Fig. 1d), enabling the mat to fix nitrogen from the atmosphere.

Oxygen measurements. In situ profiles of oxygen concentrations were determined using a gold amalgam voltammetric microelectrode according to Brendel and Luther ${ }^{71}$ (Supplementary Fig. 10). The profile was measured in 2006 directly on the outcrop hosting the mat. These measurements are thus distinct from the measurements used to construct the profiles shown in Fig. 5, which were conducted in a greenhouse with a Clark type microelectrode. We used $25-\mu \mathrm{m}$-diameter Clarktype oxygen sensors (Unisense, DK) and m-profiler software (MPI-Bremen, D) for diel oxygen concentration profile measurements. Subsamples of the mats were transferred to a greenhouse in 2009 to conduct measurements of photosynthesis and respiration. These samples were kept in flumes in a greenhouse and oxygen profiles measured under subaerial conditions and within 1 month of collection. Profiles were measured every $\sim 3$ h over a 24 -h cycle (Fig. 5a). Profiles measured at 3 a.m. and 3 p.m. were used to calculate respiration and net oxygenic photosynthesis, respectively, using a $1 \mathrm{D}$ reaction-transport model ${ }^{72}$ (Fig. $5 \mathrm{~b}, \mathrm{c}$ ). The gross photosynthesis rate was calculated as the sum of the net rate and the nighttime respiration. As respiration rates can be lower at night, due to decreased oxygen concentrations, this value represents the lower limit of gross photosynthesis in the mat.

Flux determinations from profiles. Oxygen fluxes to both the atmosphere and the underlying rock were calculated based on oxygen concentration gradients using Fick's law of diffusion:

$$
J=-\phi \times D \frac{\delta c}{\delta x},
$$

where $J$ is the diffusive flux ( $\left.\mathrm{mol} \mathrm{m}^{-2} \mathrm{y}^{-1}\right), \phi$ the porosity, $D$ the tortuositycorrected diffusion coefficient $\left(\mathrm{m}^{2} \mathrm{y}^{-1}\right)$, and $\delta c / \delta x$ the concentration gradient $\left(\mathrm{mols} \mathrm{m}^{-4}\right)$. The average porosity of the mat of 0.97 was used for all calculations. The flux to the rock was determined from an in situ profile measured with a voltammetric electrode (Supplementary Fig. 10), and the atmospheric flux from a profile measured by a Clark-type electrode in the greenhouse at a higher resolution (Fig. 5).

Oxygen fluxes from the mat to the atmosphere would be different under an anoxic atmosphere, like in the Archean Eon, than in the modern-day atmosphere with $20 \%$ oxygen. To estimate fluxes from a mat like Balambano to an anoxic atmosphere, we modelled oxygen production rates in the mat based on oxygen profiles (Supplementary Figs. 8 and 9). Oxygen concentrations were modelled as a function of rates of photosynthesis that are themselves influenced by light availability and rates of respiration, which in turn were affected by oxygen availability and described by Michaelis-Menten-type equations.
Oxygen production $\left(\mathrm{O}_{2 \text {,Prod }}\right)$ is modelled according to:

$$
\mathrm{O}_{2, \text { Prod }}=\frac{\text { PAR } \times V_{\mathrm{max}, \text { Prod }}}{\left(K_{\mathrm{m}, \text { Prod }}+\text { PAR }\right)} .
$$

Photosynthetically active radiation (PAR) was set to $1500 \mu \mathrm{E} \mathrm{m}^{-2} \mathrm{~s}^{-1}$ at the surface decreasing by $1 \%$ every depth interval of $0.071 \mathrm{~mm}$. $V_{\max , \text { Prod }}$ was set to $2.1 \mathrm{nM} \mathrm{s}^{-1} ; K_{\mathrm{m} \text {,Prod }}$ is 'the 'affinity' for light, set to $1000 \mu \mathrm{E} \mathrm{m}^{-2} \mathrm{~s}^{-1}$.

Respiration $\left(\mathrm{O}_{2, \text { Resp }}\right)$ was modelled according to:

$$
O_{2, \text { Resp }}=\frac{O_{2, n-1, x} \times V_{\max , \text { Resp }}}{\left(K_{\mathrm{m}, \text { Resp }}+O_{2, n-1, x}\right)} .
$$

$\mathrm{O}_{2, n-1, x}$ is the concentration at time $n-1$ (previous time step) and depth $x$, $V_{\text {max,Resp }}$ was set to $1.75 \mathrm{nMs}^{-1}$, and $K_{\mathrm{m} \text {,Resp }}$ was set to $250 \mathrm{nM}$ of $\mathrm{O}_{2}$.

The diffussive flux $\left(F_{\mathrm{D}}\right)$ from and to the adjacent depth $(x \pm 1)$ was modelled according to:

$$
F_{\mathrm{D}, x \pm 1}=\phi \times D^{\prime} \times \frac{O_{2, n-1, x}-O_{2, n-1, \pm 1}}{x-x_{ \pm 1}},
$$

where $\phi$ is the porosity $(0.97), D^{\prime}$ the molecular diffusivity corrected for tortuosity of $1 \times 10^{-5} \mathrm{~cm}^{2} \mathrm{~s}^{-1}, \mathrm{O}_{2, n-1, x}$ the $\mathrm{O}_{2}$ concentrations in the previous time step $(n-1)$ at depth $x, O_{2, t=n-1, x \pm 1}$ the same at the depth above $(x-1)$ or below $(x+1), x$ is the depth step that the concentration is modelled at, and $x_{ \pm 1}$ is the depth step above ( $x$ $-1)$ and below $(x+1)$.

$\mathrm{O}_{2}$ concentrations at time $n$ and depth $x$ are calculated in 1-s steps using the equation:

$$
O_{2, n, x}=O_{2, n-1,}+O_{2, \text { Prod }}-O_{2, \text { Resp }}-F_{\mathrm{D}, x-1}-F_{\mathrm{D}, x+1} .
$$

The model was parameterized to reproduce the measured $\mathrm{O}_{2}$ profiles (Fig. $5 \mathrm{~b}, \mathrm{c}$ ) and steady-state was approached within the first 1200 iterations of $1 \mathrm{~s}$ each (Supplementary Fig. 9). Next the oxygen concentration in the water was changed to $0 \mu \mathrm{M}$ and the model run again with 1200 iterations of $1 \mathrm{~s}$ each (Supplementary Figs. 8 and 9) to reach a new steady-state.

The sensitivity of the model was tested by changing the variable parameters by $\pm 10 \%$ (change of 0 and $5 \%$ for the decrease of PAR with depth) and evaluating the influence of these changes on the $\mathrm{O}_{2}$ slope across the mat-water interface at the end of the model run. This $10 \%$ change resulted in a change in the slope of $\pm 3 \%$ for the high $\mathrm{O}_{2}$ scenario and less than $\pm 1 \%$ for the no $\mathrm{O}_{2}$ scenario (Supplementary Table 7). Changes of the variable parameters had a much stronger effect on the oxygen concentrations deeper in the mat than they did on the slope at the mat-water interface.

Oxygen fluxes to the mat surface were calculated using Fick's first law with the same constants noted above. Fluxes are $6.3 \mathrm{mmol} \mathrm{m}^{-2} \mathrm{~d}^{-1}$ measured in our mats under atmospheric oxygen concentrations. Under an anoxic atmosphere, the model fluxes increase to $24 \mathrm{mmol} \mathrm{m}^{-2} \mathrm{~d}^{-1}$, which is similar to the $13 \mathrm{mmol} \mathrm{m}^{-2} \mathrm{~d}^{-1}$ calculated for hypothetical Proterozoic mats by Zhao et al. ${ }^{56}$. Zhao et al. use a much more complex modelling approach discriminating between visible and near-infrared light intensities, variable substrate concentrations, inclusion of microbial growth and death rates, and internal methane cycling. The agreement between our observations and models and their models underscores the likely extensibility of our results.

Methane flux determination. A subsample of the mat was incubated in the dark for 1.5 months and the methane production was measured in the headspace with a gas chromatograph (GC) equipped with an flame ionization detector (FID) (SRI, USA). An areal flux was determined assuming a $6-\mathrm{cm}$-thick mat. Half the flux determined by the incubation was used for the flux determinations to account for inhibition of methanogenesis under the oxic conditions that develop during the day. This flux is about 100-fold greater than the fluxes determined by Hoehler et al. ${ }^{13}$ in a modern, hypersaline microbial mat and $1 / 10$ of fluxes modelled for hypothetical Proterozoic terrestrial mats ${ }^{56}$.

Flux balance. The fluxes calculated through different approaches and considerations are compiled in a box model and converted into oxygen equivalents (normalized to $4-\mathrm{e}^{-}$transfers) for comparison (Supplementary Fig. 5). The oxygen flux to the rock and the atmosphere are modelled from in situ and greenhouse profiles, respectively. The greenhouse profiles were used to determine the atmospheric flux as they have a higher spatial resolution. OM production was calculated from the accumulation of a 6 -cm-thick mat with 0.97 porosity and the profile of the wt\% $\mathrm{C}$ (Supplementary Fig. 6), assuming accumulation over 9 years. The C-fixation rate was converted into $\mathrm{O}_{2}$ consumption based on a $4-\mathrm{e}^{-}$transfer from $\mathrm{OM}\left(\mathrm{CH}_{2} \mathrm{O}\right)$ to $\mathrm{CO}_{2}$ and a $4-\mathrm{e}^{-}$transfer from $\mathrm{O}_{2}$ to $2 \mathrm{H}_{2} \mathrm{O}$. The respiration rate was calculated from night profiles measured in the greenhouse, while the $\mathrm{CH}_{4}$ flux was determined from incubations of the mat in the dark.

Organic $\mathbf{C}$ content and $\mathbf{C}, \mathbf{N}$ isotopic compositions. The organic carbon $\left(C_{\mathrm{org}}\right)$ content, and isotopic composition, as well as the $\mathrm{N}$ isotopic composition of the mat was measured through combustion-based elemental analysis of freeze-dried subsections on an elemental analyzer coupled to an isotope ratio mass spectrometer 
(EA-IRMS; Thermo delta plus). Inorganic carbon was removed by first washing (2x) for $24 \mathrm{~h}$ with a dilute $\mathrm{HCl}(1 \mathrm{M})$ solution. The absolute instrumental reproducibility of these analyses was determined from replicate measurements of Organic Analytical Standard substances (acetanilide, atropine, cyclohexanone-2,4dinitrophenyl-hydrazone, and urea), and for concentrations estimated at $\pm 0.1 \%$ for $C_{\text {org }}$ and $\pm 0.3 \%$ for $N_{\text {TOT }}$ with a relative analytical reproducibility of $5 \%$. Isotopic data are reported in the standard $\delta$ notation with respect to V-PDB for carbon ${ }^{73}$ and atmospheric $\mathrm{N}_{2}$ for nitrogen. The analytical uncertainty on isotope ratio determinations was $\pm 0.1 \%$ for carbon and $\pm 0.2 \%$ o for nitrogen.

Inorganic solid-phase composition. The mineralogy and solid-phase chemistry of the microbial mat was determined on freeze-dried sections as described in ref. ${ }^{74}$. In brief, the mineralogy was analyzed using X-ray diffraction (XRD; Rigaku MiniFlex (Rigaku, The Woodlands, TX, USA) with $\mathrm{Cu} \mathrm{Ka}$ radiation) (Supplementary Fig. 7) and the solid-phase chemistry using X-ray fluorescence (XRF) on a lithium tetraborate fused bead using a Philips PW2440 $4 \mathrm{~kW}$ instrument (Panalytical Inc., Natick, MA, USA) (Supplementary Table 3). Accuracy for major and trace elements was within $1 \%$ and $5 \%$, respectively, based on the analyses of standard reference materials, and relative precision was within $0.5 \%$ determined by repeated analyses of the same fused bead.

Molecular microbiology. Samples for molecular microbiological analyses were subsampled in the field and frozen at $-20^{\circ} \mathrm{C}$, shipped to Denmark on dry ice, and stored frozen until extraction. The microbial mat was aseptically sectioned into three layers: top $(0-2 \mathrm{~mm})$, middle $(2-10 \mathrm{~mm})$, and bottom $(10-25 \mathrm{~mm})$ and weighed. Microbial community DNA was extracted from $\sim 0.25 \mathrm{mg}$ of microbial mat using the Power soil ${ }^{\circledR}$ DNA Isolation Kit (MoBio Laboratories, Inc., Solana Beach, CA) according to the manufacturer's protocol. The purity and quantity of DNA extracted were assessed and determined using both a NanoDrop 1000 spectrophotometer (Thermo Scientific) and the Picogreen ${ }^{\circledR}$ florescence assay.

16S rRNA gene amplicon sequencing and bioinformatic analysis. 16S rRNA gene amplicon sequences were generated by the Joint Genome Institute (Walnut Creek, CA) through a community sequencing program project (CSP-2067). Libraries for Illumina MiSeq sequencing (a $2 \times 300$ bp reads configuration) were produced by amplifying region V4-V5 of the $16 \mathrm{~S}$ rRNA gene using primers $515 \mathrm{~F}$ and 926R. DNA from all samples was amplified by PCR in triplicate using barcoded primer pairs flanking the V4-V5 region of the 16S rRNA gene as previously described ${ }^{75,76}$. Sequences were processed using Mothur ${ }^{77}$ (https://www.mothur. org/wiki/MiSeq_SOP). Briefly, sequences were removed from the analysis if they contained ambiguous characters, had homopolymers longer than $8 \mathrm{bp}$, or did not align to a reference alignment of the correct sequencing region. Unique sequences were identified and their frequency in each sample determined and then a preclustering algorithm ${ }^{78}$ was used to further de-noise sequences within each sam$\mathrm{ple}^{79}$. Unique sequences were aligned against a SILVA reference alignment (available at http://www.mothur.org/wiki/Silva_reference_alignment). Sequences were chimera checked using $\mathrm{UCHIME}^{80}$ and reads were then clustered into OTUs with $97 \%$ sequence identify using OptiClust ${ }^{81}$. OTUs were classified using SILVA reference taxonomy database (release 132, available at http://www.mothur.org/ wiki/Silva_reference_files) (Supplementary Fig. 8, Supplementary Table 4). Diversity metrics were calculated in Mothur.

qPCR and DNA content. Total bacterial 16S rRNA gene copy numbers were determined by qPCR using a bacterial-specific (27F, 5'-AGAGTTTGATCCTGGC TCAG) forward primer coupled to a universal reverse primer (DW519R, 5'-GNT TTACCGCGGCKGCTG) according to Zaikova et al. ${ }^{82}$ (Supplementary Table 5). Standards for total bacteria quantification were derived from $16 \mathrm{~S}$ rRNA gene clone libraries using a $16 \mathrm{~S}$ rRNA from the bacteria SUP05 according to Zaikova et al. ${ }^{82}$. A tenfold dilution series for each standard ranging from $3 \times 10^{2}$ to $3 \times 10^{7}$ copies $\mu \mathrm{l}^{-1}$ for bacteria was used in real-time analysis. For the purposes of this study, the limit of detection was set at the Ct values of the no template controls and was determined to be $\sim 5 \times 10^{1}$ copies $\mu^{-1}$ for all sample replicates. The quantity of DNA extracted was also used to estimate cell abundance assuming $4 \mathrm{fg}$ of DNA per cell.

Cell counts. Cell abundances were determined using epifluorescence microscopy. The mat was aseptically sectioned into three layers: top, middle, and bottom, weighed and then preserved with $2.5 \%$ (final concentration) of glutaraldehyde. The fixed samples were washed twice with phosphate-buffered saline and then dissociated form the mat matrix according to Morono et al. ${ }^{83}$. In brief, mat sections were immersed in a solution of $2.5 \% \mathrm{NaCl}$, detergent mix (100 mM EDTA, 100 $\mathrm{mM}$ sodium pyrophosphate, $1 \%(\mathrm{v} / \mathrm{v})$ Tween 80$)$, and methanol, then vigorously shaken for $120 \mathrm{~min}$ at $500 \mathrm{rpm}$. After shaking, the mat sections were sonicated and then carefully layered onto a $50 \%(\mathrm{w} / \mathrm{v})$ Nycodenz solution ${ }^{84}$. Samples were centrifuged at $4500 \times g$ for $30 \mathrm{~min}$ after which the supernatant, including the highdensity layer(s), was carefully removed and transferred to a separate vial. Cells were visualized following staining with DAPI using an eipfluorescence microscope (Zeiss, axioscope) with a $40 \times$ objective lens and enumerated using a bright line counting chamber (Hausser scientific) (Supplementary Table 5). The mat consisted of a large number of small bacterial cells and a relatively small number of larger, filamentous microbes. The DAPI counts only represent the small bacterial cells, as the larger filaments were not separated from the matrix. The general agreement between DAPI counts and q-PCR, as well as quantification of DNA yields, gives us confidence that visual enumeration captured the vast majority of the cells. Our cell counts lie at the lower end of previously reported values for mats ${ }^{85}$, and this is in line with the minimum values we report.

Calculation of cellular carbon and cell divisions in subaerial mats. To calculate cellular biomass, we considered cell abundances of $10^{8}-10^{9}$ cells $\mathrm{cm}^{-3}$ and cellular carbon contents of $1-150 \mathrm{fg} \mathrm{C}$ cell $^{-1}$ (refs. ${ }^{86-88}$ ). This translates to between $10^{-7}$ and $1.5 \times 10^{-4} \mathrm{~g} \mathrm{C} \mathrm{cm}^{-3}$ of wet mat. Based on a porosity of 0.97 and a particle bulk density of $2.65 \mathrm{~g} \mathrm{~cm}^{-3}$, the total organic carbon content of $1-12 \%$ dry mass translates to carbon concentrations in the wet mat of between $0.7 \times 10^{-4}$ and $9.5 \times$ $10^{-3} \mathrm{~g} \mathrm{C} \mathrm{cm}^{-3}$. This means that cellular biomass accounts for between 0.001 and $20 \%$ of the total organic carbon. Cell counts (Supplementary Table 6) and gross photosynthesis rates (Fig. 5) were used to calculate a cell turnover time in the mats based on 1-150 fg of $C$ per cell ${ }^{86-88}$. Cell counts of the top section were used, as the locus of photosynthesis is within this depth interval (Fig. 5b). This resulted in a turnover time of $0.2 \mathrm{~d}$ or 5 divisions per cell per day. Based on the range in $\mathrm{C}$ concentrations per cell, this results in $6.9 \times 10^{22}$ to $1.0 \times 10^{25}$ divisions per day for $0.1 \%$ continental coverage by microbial mats $6.9 \times 10^{25}$ to $1.0 \times 10^{28}$ divisions per day for $100 \%$ continental coverage (Supplementary Fig. 10, Supplementary Table 7). Archean ocean surface area was calculated based on a land area of $5 \%$ leaving an ocean area of $95 \%$ of the earth surface or $485 \times 10^{6} \mathrm{~km}^{2}$. Using cell densities and turnover times for the surface ocean according to Whitman et al..$^{55}$ and a tenfold lower primary productivity than the modern results in $4.8 \times 10^{27}$ cells and $2-8 \times 10^{26}$ divisions per day (Supplementary Fig. 10, Supplementary Table 7)

Eukaryotes. Microeukaryotes, including diatoms and algae, were visible through microscopy, but were not directly analyzed through, for example, amplicon sequencing of the 18S rRNA gene or ITS regions. 16S rRNA gene sequences recovered from mitochondria and chloroplasts, however, were rare in our amplicon sequence data and this is at least qualitatively consistent with our limited observations of Eukaryotes through microscopy. For example, chloroplast reads represented $<0.2 \%$ of all reads and $<2 \%$ of all photosynthetic reads (Supplementary Table 8). Photosynthesis and respiration by microeukaryotes would have been integrated into our rate measurements, but their likely very low abundance, compared to bacteria, implies that they play a limited role. We do recognize, however, that abundance is not a good proxy for activity, but given the extreme dominance of bacteria here, we argue that they also play the most important role.

\section{Data availability}

Sequence data that support the findings of this study have been deposited into the SRA database under SRA accession: SRP155785. Additional data that support the findings of this study are available from the corresponding author upon request.

Received: 3 August 2018 Accepted: 3 July 2019

Published online: 20 September 2019

\section{References}

1. Field, C. B., Behrenfeld, M. J., Randerson, J. T. \& Falkowski, P. Primary production of the biosphere: Integrating terrestrial and oceanic components. Science 281, 237-240 (1998).

2. Bergman, N. M., Lenton, T. M. \& Watson, A. J. COPSE: A new model of biogeochemical cycling over Phanerozoic time. Am. J. Sci. 304, 397-437 (2004)

3. Quirk, J. et al. Constraining the role of early land plants in Palaeozoic weathering and global cooling. Proc. Biol. Sci. 282, 20151115 (2015).

4. Horodyski, R. J. \& Knauth, L. P. Life on land in the Precambrian. Science $\mathbf{2 6 3}$ 494-498 (1994).

5. Stueken, E. E., Catling, D. C. \& Buick, R. Contributions to late Archaean sulphur cycling by life on land. Nat. Geosci. 5, 722-725 (2012).

6. Knauth, L. P. \& Kennedy, M. J. The late Precambrian greening of the Earth Nature 460, 728-732 (2009).

7. Watanabe, Y., Martini, J. E. J. \& Ohmoto, H. Geochemical evidence for terrestrial ecosystems 2.6 billion years ago. Nature 408, 574-578 (2000).

8. Homann, M. et al. Microbial life and biogeochemical cycling on land 3,220 million years ago. Nat. Geosci. 11, (2018).

9. Canfield, D. E. \& Marais, D. J. D. Biogeochemical cycles of carbon, sulfur, and free oxygen in a microbial mat. Geochim. Cosmochim. Acta 57, 3971-3984 (1993).

10. Finke, N., Hoehler, T. M., Polerecky, L., Buehring, B. \& Thamdrup, B. Competition for inorganic carbon between oxygenic and anoxygenic 
phototrophs in a hypersaline microbial mat, Guerrero Negro, Mexico. Environ. Microbiol. 15, 1432-1550 (2013).

11. Des Marais, D. J. Biogeochemistry of hypersaline microbial mats illustrates the dynamics of modern microbial ecosystems and the early evolution of the biosphere. Biol. Bull. 204, 160-167 (2003).

12. Canfield, D. E., Sørensen, K. B. \& Oren, A. Biogeochemistry of a gypsumencrusted microbial ecosystem. Geobiology 2, 133-150 (2004).

13. Hoehler, T. M., Bebout, B. M. \& Des Marais, D. J. The role of microbial mats in the production of reduced gases on the early Earth. Nature 412, 324-327 (2001).

14. Houghton, J. et al. Spatial variability in photosynthetic and heterotrophic activity drives localized delta C-13(org) fluctuations and carbonate precipitation in hypersaline microbial mats. Geobiology 12, 557-574 (2014).

15. Grotzschel, S. \& de Beer, D. Effect of oxygen concentration on photosynthesis and respiration in two hypersaline microbial mats. Microb. Ecol. 44, 208-216 (2002).

16. Ley, R. E. et al. Unexpected diversity and complexity of the Guerrero Negro hypersaline microbial mat. Appl. Environ. Microbiol. 72, 3685-3695 (2006).

17. Harris, J. K. et al. Phylogenetic stratigraphy in the Guerrero Negro hypersaline microbial mat. ISME J. 7, 50-60 (2013).

18. Nowack, S. et al. The molecular dimension of microbial species: 2 . Synechococcus strains representative of putative ecotypes inhabiting different depths in the Mushroom Spring microbial mat exhibit different adaptive and acclimative responses to light. Front. Microbiol. 6, 626 (2015).

19. Des Marais, D. Microbial mats and the early evolution of life. Trends Ecol. Evol. 5, 140-144 (1990).

20. Jorgensen, B. B., Revsbech, N. P., Blackburn, T. H. \& Cohen, Y. Diurnal cycle of oxygen and sulfide microgradients and microbial photosynthesis in a cyanobacterial mat sediment. Appl. Environ. Microbiol. 38, 46-58 (1979).

21. Walsh, E. A., Smith, D. C., Sogin, M. L. \& D’Hondt, S. Bacterial and archaeal biogeography of the deep chlorophyll maximum in the South Pacific Gyre. Aquat. Microb. Ecol. 75, 1 (2015).

22. Wagg, C., Bender, S. F., Widmer, F. \& van der Heijden, M. G. Soil biodiversity and soil community composition determine ecosystem multifunctionality. Proc. Natl Acad. Sci. USA 111, 5266-5270 (2014).

23. Roesch, L. F. et al. Pyrosequencing enumerates and contrasts soil microbial diversity. ISME J. 1, 283-290 (2007).

24. Schirrmeister, B. E., de Vos, J. M., Antonelli, A. \& Bagheri, H. C. Evolution of multicellularity coincided with increased diversification of cyanobacteria and the Great Oxidation Event. Proc. Natl Acad. Sci. USA 110, 1791-1796 (2013).

25. Magnabosco, C., Moore, K. R., Wolfe, J. M. \& Fournier, G. P. Dating phototrophic microbial lineages with reticulate gene histories. Geobiology 16, 179-189 (2018).

26. Daims, H. et al. Complete nitrification by Nitrospira bacteria. Nature $\mathbf{5 2 8}$, 504-509 (2015).

27. Chistoserdova, L., Chen, S.-W., Lapidus, A. \& Lidstrom, M. E. Methylotrophy in Methylobacterium extorquens AM1 from a genomic point of view. $J$. Bacteriol. 185, 2980-2987 (2003).

28. Treusch, A. H. et al. Novel genes for nitrite reductase and Amo-related proteins indicate a role of uncultivated mesophilic crenarchaeota in nitrogen cycling. Environ. Microbiol. 7, 1985-1995 (2005).

29. Spang, A. et al. The genome of the ammonia-oxidizing $\mathrm{C}$ andidatus $\mathrm{N}$ itrososphaera gargensis: insights into metabolic versatility and environmental adaptations. Environ. Microbiol. 14, 3122-3145 (2012).

30. Lomans, B. P. et al. Isolation and characterization of Methanomethylovorans hollandica gen. nov., sp. nov., isolated from freshwater sediment, a methylotrophic methanogen able to grow on dimethyl sulfide and methanethiol. Appl. Environ. Microbiol 65, 3641-3650 (1999).

31. Evans, P. N. et al. Methane metabolism in the archaeal phylum Bathyarchaeota revealed by genome-centric metagenomics. Science $\mathbf{3 5 0}$, 434-438 (2015).

32. Park, R. \& Epstein, S. Carbon isotope fractionation during photosynthesis. Geochim. Cosmochim. Acta 21, 110-126 (1960).

33. Redfield, A. C. The biological control of chemical factors in the environment. Am. Sci. 46, 205-221 (1958).

34. Planavsky, N. J. The elements of marine life. Nat. Geosci. 7, 855-856 (2014).

35. Hoering, T. C. \& Ford, H. T. The isotope effect in the fixation of nitrogen by azotobacter. J. Am. Chem. Soc. 82, 376-378 (1960).

36. Prave, A. R. Life on land in the Proterozoic: evidence from the Torridonian rocks of northwest Scotland. Geology 30, 811-814 (2002).

37. Retallack, G. J., Krinsley, D. H., Fischer, R., Razink, J. J. \& Langworthy, K. A. Archean coastal-plain paleosols and life on land. Gondwana Res. 40, 1-20 (2016).

38. Buick, R. The antiquity of oxygenic photosynthesis: evidence from stromatolites in sulphate-deficient Archaean lakes. Science 255, 74-77 (1992).

39. Tice, M. M., Thornton, D. C. O., Pope, M. C., Olszewski, T. D. \& Gong, J. Archean microbial mat communities. Annu. Rev. Earth Planet. Sci. 39, 297-319 (2011).
40. Tice, M. M. \& Lowe, D. R. Photosynthetic microbial mats in the 3,416-Myrold ocean. Nature 431, 549-552 (2004).

41. Kennedy, M., Droser, M., Mayer, L. M., Pevear, D. \& Mrofka, D. Late Precambrian oxygenation; inception of the clay mineral factory. Science 311, 1446-1449 (2006).

42. Hazen, R. M. et al. Clay mineral evolution. Am. Mineral. 98, 2007-2029 (2013).

43. Thomazo, C., Couradeau, E. \& Garcia-Pichel, F. Possible nitrogen fertilization of the early Earth Ocean by microbial continental ecosystems. Nat. Commun. 9, 2530 (2018).

44. Lalonde, S. V. \& Konhauser, K. O. Benthic perspective on Earth's oldest evidence for oxygenic photosynthesis. Proc. Natl Acad. Sci. USA 112, 995-1000 (2015).

45. Louca, S. et al. Bacterial diversification through geological time. Nat. Ecol. Evol. 2, 1458 (2018).

46. David, L. A. \& Alm, E. J. Rapid evolutionary innovation during an Archaean genetic expansion. Nature 469, 93-96 (2011).

47. Falkowski, P. G., Fenchel, T. \& Delong, E. F. The microbial engines that drive Earth's biogeochemical cycles. Science 320, 1034-1039 (2008).

48. Louca, S. et al. Function and functional redundancy in microbial systems. Nat. Ecol. Evol. 2, 936-943 (2018).

49. Canfield, D. E., Rosing, M. T. \& Bjerrum, C. Early anaerobic metabolisms. Philos. Trans. R Soc. Lond. B Biol. Sci. 361, 1819-1836 (2006).

50. Flament, N., Coltice, N. \& Rey, P. F. The evolution of the Sr-87/Sr-86 of marine carbonates does not constrain continental growth. Precambrian Res. 229, 177-188 (2013).

51. Korenaga, J., Planavsky, N. J. \& Evans, D. A. D. Global water cycle and the coevolution of the Earth's interior and surface environment. Philos. Trans. $R$ Soc. A Math. Phys. Eng. Sci. 375, 20150393 (2017).

52. Raymond, P. A. et al. Global carbon dioxide emissions from inland waters. Nature 503, 355-359 (2013).

53. Keenan, R. J. et al. Dynamics of global forest area: results from the FAO Global Forest Resources Assessment 2015. For. Ecol. Manag. 352, 9-20 (2015).

54. Sterling, S. \& Ducharne, A. Comprehensive data set of global land cover change for land surface model applications. Global Biogeochem. Cycles 22 (2008).

55. Whitman, W. B., Coleman, D. C. \& Wiebe, W. J. Prokaryotes: the unseen majority. Proc. Natl Acad. Sci. USA 95, 6578-6583 (1998).

56. Zhao, M., Reinhard, C. T. \& Planausky, N. Terrestrial methane fluxes and Proterozoic climate. Geology 46, 139-142 (2017)

57. Katsev, S. \& Crowe, S. A. Organic carbon burial efficiencies in sediments: the power law of mineralization revisited. Geology 43, 607-610 (2015).

58. Izon, G. et al. Biological regulation of atmospheric chemistry en route to planetary oxygenation. Proc. Natl Acad. Sci. USA 114, E2571-E2579 (2017).

59. Eickmann, B. et al. Isotopic evidence for oxygenated Mesoarchaean shallow oceans. Nat. Geosci. 11, 133 (2018).

60. Wille, M. et al. Evidence for a gradual rise of oxygen between 2.6 and $2.5 \mathrm{Ga}$ from Mo isotopes and Re-PGE signatures in shales. Geochim. Cosmochim. Acta 71, 2417-2435 (2007).

61. Crowe, S. A. et al. Atmospheric oxygenation three billion years ago. Nature 501, 535-538 (2013).

62. Planavsky, N. J. et al. Evidence for oxygenic photosynthesis half a billiion years before the Great Oxidation Event. Nat. Geosci. 7, 283-286 (2014).

63. Cardona, T., Sanchez-Baracaldo, P., Rutherford, A. W. \& Larkum, A. W. Early Archean origin of Photosystem II. Geobiology 17, 127-150 (2019).

64. Castresana, J., Lübben, M., Saraste, M. \& Higgins, D. G. Evolution of cytochrome oxidase, an enzyme older than atmospheric oxygen. EMBO J. 13, 2516-2525 (1994).

65. Stolper, D. A., Revsbech, N. P. \& Canfield, D. E. Aerobic growth at nanomolar oxygen concentrations. Proc. Natl Acad. Sci. USA 107, 18755-18760 (2010).

66. Thomazo, C., Ader, M. \& Philippot, P. Extreme $15 \mathrm{~N}$-enrichments in 2.72 Gyr-old sediments: evidence for a turning point in the nitrogen cycle. Geobiology 9, 107-120 (2011).

67. Zerkle, A. L. et al. Onset of the aerobic nitrogen cycle during the Great Oxidation Event. Nature 542, 465 (2017)

68. Garvin, J., Buick, R., Anbar, A. D., Arnold, G. L. \& Kaufman, A. J. Isotopic evidence for an aerobic nitrogen cycle in the Latest Archean. Science 323, 1045-1048 (2009).

69. Ader, M. et al. Interpretation of the nitrogen isotopic composition of Precambrian sedimentary rocks: assumptions and perspectives. Chem. Geol. 429, 93-110 (2016)

70. Reinhard, C. T., Raiswell, R., Scott, C., Anbar, A. D. \& Lyons, T. W. A Late Archean sulfidic sea stimulated by early oxidative weathering of the continents. Science 326, 713-716 (2009).

71. Brendel, P. J. \& Luther, G. W. Development of a gold amalgam voltammetric microelectrode for the determination of dissolved $\mathrm{Fe}, \mathrm{Mn}, \mathrm{O}-2$, and $\mathrm{S}(-\mathrm{Ii})$ in porewaters of marine and fresh-water sediments. Environ. Sci. Technol. 29, 751-761 (1995) 
72. Berg, P., Risgaard-Petersen, N. \& Rysgaard, S. Interpretation of measured concentration profiles in sediment pore water. Limnol. Oceanogr. 43, 1500-1510 (1998).

73. Coplen, T. B. Discontinuance of SMOW and PDB. Nature 375, 285-285 (1995).

74. Crowe, S. A., Roberts, J. A., Weisener, C. G. \& Fowle, D. A. Alteration of ironrich lacustrine sediments by dissimilatory iron-reducing bacteria. Geobiology 5, 63-73 (2007).

75. Parada, A. E., Needham, D. M. \& Fuhrman, J. A. Every base matters: assessing small subunit rRNA primers for marine microbiomes with mock communities, time series and global field samples. Environ. Microbiol. 18, 1403-1414 (2015).

76. Caporaso, J. G. et al. Ultra-high-throughput microbial community analysis on the Illumina HiSeq and MiSeq platforms. ISME J. 6, 1621-1624 (2012).

77. Schloss, P. D. et al. Introducing mothur: open-source, platform-independent, community-supported software for describing and comparing microbial communities. Appl. Environ. Microbiol. 75, 7537-7541 (2009).

78. Huse, S. M., Welch, D. M., Morrison, H. G. \& Sogin, M. L. Ironing out the wrinkles in the rare biosphere through improved OTU clustering. Environ. Microbiol. 12, 1889-1898 (2010).

79. Schloss, P. D., Gevers, D. \& Westcott, S. L. Reducing the effects of PCR amplification and sequencing artifacts on 16S rRNA-Based Studies. PLoS ONE 6, e27310 (2011).

80. Edgar, R. C., Haas, B. J., Clemente, J. C., Quince, C. \& Knight, R. UCHIME improves sensitivity and speed of chimera detection. Bioinformatics 27, 2194-2200 (2011).

81. Westcott, S. L. \& Schloss, P. D. OptiClust: improved method for assigning amplicon-based sequence data to operational taxonomic units. bioRxiv e00073-17 (2016).

82. Zaikova, E. et al. Microbial community dynamics in a seasonally anoxic fjord: Saanich Inlet, British Columbia. Environ. Microbiol. 12, 172-191 (2010).

83. Morono, Y., Terada, T., Kallmeyer, J. \& Inagaki, F. An improved cell separation technique for marine subsurface sediments: applications for highthroughput analysis using flow cytometry and cell sorting. Environ. Microbiol. 15, 2841-2849 (2013).

84. Kallmeyer, J., Smith, D. C., Spivack, A. J. \& D'Hondt, S. New cell extraction procedure applied to deep subsurface sediments. Limnol. Oceanogr. Methods 6, 236-245 (2008).

85. Carreira, C., Staal, M., Middelboe, M. \& Brussaard, C. P. D. Counting viruses and bacteria in photosynthetic microbial mats. Appl. Environ. Microbiol. 81, 2149-2155 (2015).

86. Gundersen, K., Heldal, M., Norland, S., Purdie, D. A. \& Knap, A. H. Elemental $\mathrm{C}, \mathrm{N}$, and $\mathrm{P}$ cell content of individual bacteria collected at the Bermuda Atlantic Time-Series Study (BATS) site. Limnol. Oceanogr. 47, 1525-1530 (2002).

87. Vrede, K., Heldal, M., Norland, S. \& Bratbak, G. Elemental composition (C, N, $\mathrm{P})$ and cell volume of exponentially growing and nutrient-limited bacterioplankton. Appl. Environ. Microbiol. 68, 2965-2971 (2002).
88. Fukuda, R., Ogawa, H., Nagata, T. \& Koike, I. Direct determination of carbon and nitrogen contents of natural bacterial assemblages in marine environments. Appl. Environ. Microbiol. 64, 3352-3358 (1998).

\section{Acknowledgements}

PT Vale Indonesia Tbk and their staff provided access to the Balambano dam site and logistical support in the field. Tri Widiyanto and his staff from the Indonesia Research Center for Limnology provided administrative support in obtaining the Scientific Research Permit. Meghan Wise provided the original art in Fig. 2. Christopher Weisener and David Porta-Tena made helpful suggestions, as did several anonymous reviewers, to whom we are grateful.

\section{Author contributions}

S.A.C., N.F. and D.A.F. conceived the study; S.A.C., A.H.O., D.A.F., C.H. and S.N performed the field work; N.F., S.A.C., R.L.S. and A.H.O. conducted the analyses; N.F., R L.S. and S.A.C. wrote the manuscript with input from all co-authors including L.C.M., D.E.C., K.K. and S.V.L.

\section{Additional information}

Supplementary Information accompanies this paper at https://doi.org/10.1038/s41467 019-11541-x.

Competing interests: The authors declare no competing interests.

Reprints and permission information is available online at http://npg.nature.com/ reprintsandpermissions/

Peer review information Nature Communications would like to thank Christophe Dupraz and the other, anonymous, reviewers for their contribution to the peer review of this work.

Publisher's note Springer Nature remains neutral with regard to jurisdictional claims in published maps and institutional affiliations.

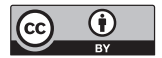

Open Access This article is licensed under a Creative Commons Attribution 4.0 International License, which permits use, sharing, adaptation, distribution and reproduction in any medium or format, as long as you give appropriate credit to the original author(s) and the source, provide a link to the Creative Commons license, and indicate if changes were made. The images or other third party material in this article are included in the article's Creative Commons license, unless indicated otherwise in a credit line to the material. If material is not included in the article's Creative Commons license and your intended use is not permitted by statutory regulation or exceeds the permitted use, you will need to obtain permission directly from the copyright holder. To view a copy of this license, visit http://creativecommons.org/licenses/by/4.0/.

(C) The Author(s) 2019 